\title{
The Pan-African Parliament of the African Union: Composition, man- date and partnerships, and its quest for sustainable development
}

\author{
Oliver C. Ruppel \& Larissa-Jane Houston
}

As initially envisioned under the Organisation of African Unity (OAU) to be established by the African Economic Community (AEC), the Pan-African Parliament (PAP) was successfully established when the African Union (AU) replaced the OAU and called for the speedy establishment of the institutions provided for in the AEC Treaty (Abuja Treaty). ${ }^{1}$

The OAU, predecessor of the AU, was established on 25 May 1963 in Addis Ababa, Ethiopia. ${ }^{2}$ Twenty years after the establishment of the OAU Charter Review Committee, the OAU's Assembly of African Heads of State and Government met at Sirte, Libya, on 9 September 1999, for its Fourth Extraordinary Summit where it adopted the Sirte Declaration proposing an Inter-African Union, or African Union, as it would later be known. ${ }^{3}$ The meeting of the Fourth Extraordinary Summit sought to:

discuss ways and means of making the OAU effective so as to keep pace with political and economic developments taking place in the world and the preparation required of Africa within the context of globalization so as to preserve its socio-economic and political potentials. ${ }^{4}$

Article 8 of the Sirte Declaration provided the following:

Having discussed frankly and extensively on how to proceed with the strengthening of the unity of our continent and its peoples, in the light of those proposals, and bearing in mind the current situation on the Continent, we decide to: (i) Establish an African Union, in conformity with the ultimate objectives of the Charter of our Continental Organization and the provisions of the Treaty establishing the African Economic Community. ${ }^{5}$

1 PAP (2020); Magliveras \& Naldi (2003).

2 Charter of the Organization of African Unity (adopted 25 May 1963, entered into force 13 September 1963).

3 Murray (2004: 22).

4 OAU (1999).

5 Organisation of African Unity (Assembly of Heads of State and Government) Sirte Declaration (Sirte 1999) EAHG/Draft/Decl. (IV) Rev.1. 
The legal basis of the PAP is provided for within the Abuja Treaty. ${ }^{6}$ According to Article 5(1)(c) of the Constitutive Act of the AU, ${ }^{7}$ the PAP is considered to be an organ of the AU. Article 5 of the AU Constitutive Act provides for the establishment of the following institutions: The Assembly; the Executive Council; the Specialised Technical Committees; the Pan-African Parliament; the African Court of Justice (and Human Rights) $;{ }^{8}$ the financial institutions; the Commission; the Permanent Representatives Committee; the Economic, Social and Cultural Council; and other organs that the Assembly may decide to establish. Each of these has its own mandate and focus areas within the African Union.

Article 17 of the Constitutive Act of the AU pertains specifically to the PAP and provides that, in order to ensure the full participation of African peoples in the development and economic integration of the continent, a Pan-African Parliament will be established. The composition, powers, functions, and organisation of the Pan-African Parliament will be defined in a protocol relating thereto.

Article 17(1) of the Constitutive Act provides the purpose of the PAP in the AU context. According to the PAP, "the Parliament is intended as a platform for people from all African states to be involved in discussions and decision-making on the problems and challenges facing the continent." $\mathrm{A}$ joint reading of the purposes as provided by the AU and the PAP indicate an expectation that the PAP will provide a shared platform for African peoples that includes involvement from grassroots organisations. ${ }^{10}$

The Protocol to the Constitutive Act of the African Union Relating to the Pan-African Parliament (PAP Protocol) assists with directing the objectives and functions of the PAP. ${ }^{11}$ According to the PAP: ${ }^{12}$

the mission of the Pan-African Parliament is to provide a common platform for African peoples to represent, and to act as a voice of the people of Africa presenting their opinions, their concerns and aspirations, and thus effectively hold the governing institutions of the AU accountable in the implementation of policies and programmes as well as in the allocation and use of public resources for promoting just, equitable and sustainable development for all the peoples of Africa. The ultimate aim of the Pan-African Parliament is to evolve into an institution with full legislative powers, whose members are elected by universal adult suffrage.

6 Dinokopila (2013); Organisation of African Unity (Assembly of Heads of State and Government) Treaty Establishing the African Economic Community (Abuja Treaty) entered into force 12 May 1994, Article 14.

7 OAU Doc. CAB/LEG/23.15.

8 See also Protocol on the Statute of the African Court of Justice and Human Rights (Single Protocol) Article 3 (adopted July 2008).

9 PAP (2020).

10 Magliveras \& Naldi (2003).

11 Adopted 27 June 2014.

12 PAP (2020). 
According to Article 2(3) of the PAP Protocol, the PAP represents all the peoples of Africa. It is at present composed of 229 members of parliament representing 52 of 55 African countries and as such receives its mandate from each member state. ${ }^{13}$ PAP membership includes five members elected by each member state, of which at least two are women. ${ }^{14}$ The national parliaments or other legislative bodies of each member state elect or designate members to the PAP to represent the interests of each member state. ${ }^{15}$ The expectations and qualifications that should be considered during the election process are provided for under Article 5 of the PAP Protocol. The PAP Protocol provides that:

In addition to the condition on women's representation, the membership of each Member State must reflect the diversity of political opinions in each National Parliament or other deliberative organ. The term of Members of the Pan-African Parliament starts from the day they are sworn into office or make a solemn declaration during a plenary session. While exercising their functions, Members of the Pan-African Parliament shall enjoy immunities and privileges in the territory of each Member State. ${ }^{16}$

As provided under Article 2(2) of the PAP Protocol, the organs of the PAP will be the plenary; the bureau; the secretariat, committees and regional groups. According to Article 12(3) of the PAP Protocol, the Bureau is responsible for the development of policies for the management and administration of the affairs and property of the PAP, which must be submitted to the plenary for approval. The Rules of Procedure, as established under Article 11 of the PAP Protocol, will provide the specific functions of the President and Vice-President of the PAP. The PAP's Secretary-General is the head of the Secretariat and thus responsible for the day-to-day management and administration of the affairs and property of the PAP and is accountable to the PAP through the Bureau, as outlined in Article 13(4) of the PAP Protocol.

Article 9 of the PAP Protocol stipulates privileges and immunities of the PAP parliamentarians, which relate to diplomatic relations and parliamentary immunity in each member state. The PAP consists of 11 permanent committees to assist with issues that are placed before Parliament - in particular the Committee on Rural Economy, Agriculture, Natural Resources and Environment; the Committee on Monetary and Financial Affairs; the Committee on Trade, Customs and Immigration Matters; the Committee on Cooperation, International Relations and Conflict Resolutions; the Committee on Transport, Industry, Communication, Energy, Science and Technology; the Committee on Health, Labour and Social Affairs; the Committee on Education, Culture, Tourism and Human Resources; the Committee on Gender, Family, Youth 
and People with Disabilities; the Committee on Justice and Human Rights; the Committee on Rules, Privileges and Discipline; and the Committee on Audit and Public Accounts. ${ }^{17}$

General functions of these permanent committees are set out under Rule 22(11) of the PAP Rules of Procedure, which provide at the outset that "the President shall, on the advice of the Bureau, determine the business to be handled by the Committees" and that Parliament may allocate any other matter to any committee it deems appropriate, in accordance with Rule 25(3) of the PAP Rules of Procedure. ${ }^{18}$

\section{Mandate}

Upon its establishment, the broad mandate of the PAP was to "enable all the peoples of Africa to get involved in discussions and decision-making on the problems and challenges which beset Africa". ${ }^{19}$ The understanding was that the PAP would represent a common continental (African) vision that would "strengthen the African Union". ${ }^{20}$ The specific mandate of the PAP is set out as objectives, functions and powers provided by the PAP Protocol.

The specific objectives of the Pan-African Parliament are to give a voice to the African peoples and the diaspora; facilitate the effective implementation of the policies and objectives of the African Union; promote the principle of human rights and democracy in Africa; encourage good governance, transparency and accountability in member states; familiarise the peoples of Africa with the objectives and policies on the political and socioeconomic integration of the continent; promote peace, security and stability; contribute to a more prosperous future for the peoples of Africa by promoting collective self-reliance and economic recovery; facilitate cooperation and development in Africa; strengthen continental solidarity and build a sense of common destiny among the peoples of Africa; facilitate cooperation among regional economic communities, ${ }^{21}$ and their parliamentary forums; encourage national and regional parliaments to ratify and integrate treaties adopted by the AU into their legal systems; cooperate with national and regional parliaments and similar bodies within and outside

17 Dinokopila (2013); PAP (2020).

18 Pan-African Parliament (Ad Hoc Rules Committee) Rules of Procedure adopted on 21 November 2004.

19 Mngomezulu (2018).

20 Ibid.: 50.

21 The AU recognises eight RECs: the Arab Maghreb Union (UMA); the Common Market for Eastern and Southern Africa (COMESA); the Community of Sahel-Saharan States (CEN$\mathrm{SAD}$ ); the East African Community (EAC); the Economic Community of Central African States (ECCAS); the Economic Community of West African States (ECOWAS); the Intergovernmental Authority on Development (IGAD); and the Southern African Development Community (SADC). 
Africa, as well as civil societies, community-based organisations and grassroots organisations; and invite and encourage the full participation of the African diaspora as an important part of the African peoples in the building of the African Union in accordance with modalities approved by the Assembly. ${ }^{22}$ A key objective of the PAP is to encourage good governance and to promote the principles of human rights and democracy in Africa. ${ }^{23}$

\section{$4 \quad$ Functions and powers}

According to Article 8 of the PAP Protocol, the PAP is the legislative organ of the AU and is responsible for carrying out the functions and wielding the powers of the AU. Article 8 of the PAP Protocol specifically states that: ${ }^{24}$

The Assembly shall determine the subjects/areas on which the PAP may propose draft model laws; The PAP may on its own make proposals on the subjects/areas on which it may submit or recommend draft Model Laws to the Assembly for its consideration and approval; The PAP shall also: receive and consider reports of other organs of the AU as may be referred to it by the Council or the Assembly, including audit and other reports and make recommendations thereon, debate and discuss its own budget and the budget of the Union and make recommendations thereon to the relevant policy organs, establish any Parliamentary Committee and determine its functions, mandate, composition and term of office, discuss any matter relevant to the AU and make recommendations to the Council or the Assembly as it may deem appropriate, make proposals to the Council on the structure of the Secretariat of the Parliament taking into account its needs, request the attendance of officials of the other organs of the AU at its sessions to offer assistance to the Parliament in the discharge of its duties, promote the programmes and objectives of $\mathrm{AU}$ in Member states, receive, consider and submit opinions on draft legal instruments, treaties and other international agreements as may be referred to it by the Council or Assembly, liaise with National Parliaments or other deliberative bodies and the Parliaments of the Regional Economic Communities on all matters relating to the AU and regional integration in Africa, and carry out such other activities as it deems appropriate to achieve the objectives set out in Article 3 of the PAP Protocol.

\section{Moreover, the PAP has powers to:}

discuss and make recommendations on issues relating to human rights, democracy and good governance, to harmonise the laws of member states, make recommendations contributing to the objectives of the AU/AEC, promote the AU/AEC in the member states, and to harmonise the policies and programmes of regional economic communities. ${ }^{25}$

24 African Union Protocol to the Constitutive Act of the African Union relating to the Pan-African Parliament, at https://au.int/en/treaties/protocol-constitutive-act-african-union-relating-pan-african-parliament, accessed 27 May 2020.

Magliveras \& Naldi (2003). 
Given that the PAP is responsible, under Article 3 of the PAP Protocol, for cooperation among regional economic communities (RECs), as well as member states and specialised organisations across the continent, there are a number of partnerships established and supported by the PAP.

Article 19(1) of the PAP Protocol provides that the PAP is required to "work in close co-operation with the Parliaments of the RECs and the National Parliaments or other Organs of Member States."

Article 20 of the PAP Protocol regulates the relations between the PAP and other organs of the AU. These provisions underpin the partnerships between the PAP and member states and the AU. The meaning of 'close cooperation' as provided in the PAP Protocol has not been entirely clarified and is interpreted as the possibility that Parliament will convene annual consultative meetings with the other entities to discuss matters of common interest. ${ }^{26}$

The communication with the relevant RECs is through the East African Legislative Assembly operating in the East African Community; the Southern African Development Community (SADC) Parliamentary Forum; the Economic Community of West African States (ECOWAS) Parliament; and the Economic and Monetary Community of Central Africa (CEMAC) Parliament. ${ }^{27}$

Despite shortcomings faced by the PAP, there have been a number of successfully executed projects and initiatives by the PAP that have been crucial to the achievement of its mandate. The PAP has sought to address challenges through the passing of a number of resolutions, for example those passed at the 3rd Ordinary Session, namely the resolutions on signing of adherence to the African Peer Review Mechanism (PAP_Res.001/05); on the development of a continental code of conduct on the use and exploitation of National Resources and Environmental Protection (PAP_Res.002/05); on the appreciation of the intervention of the Chairperson of the African Union in the Togo crisis (PAP_Res.003/05); on the appreciation of the work of Mr Kofi Annan, the Secretary-General to the United Nations (PAP_Res.004/05); relating to the presidential elections in Togo on 24 April 2005 (PAP_Res.005/05); on the dispatch of the Pan-African Parliament Peace Mission to Cote d'Ivoire at the beginning of May 2005 (PAP_Res.006/05); and on congratulating His Excellency Thabo Mbeki, President of the Republic of South Africa, on his success in achieving a peace agreement between the warring parties in Cote d'Ivoire (PAP_Res.007/05). ${ }^{28}$

26 Ibid.

27 Ibid.

28 Amadi (2016: 5). 
The PAP has also looked to strengthen its legislative arm in countries across Africa, in general, through the African Peer Review Mechanism (APRM): ${ }^{29}$

The APRM is a mutually agreed instrument voluntarily acceded to by AU Member States as an African self-monitoring mechanism. The APRM is often described as Africa's unique and innovative approach to governance with the objective of improving governance dynamics at the local, national and continental levels. ${ }^{30}$

The APRM conducts individual governance reviews in specific countries and, once the review is completed, writes a country review report and presents it before the PAP. ${ }^{31}$ This is in compliance with the APRM base document which provides that six months after each country review report has been considered by the Heads of State and Government of the participating member countries, it should be formally and publicly tabled in key regional and sub-regional structures such as the PAP. ${ }^{32}$

Another such partnership occurs between the Chairperson of the African Union Peace and Security Council, who routinely attends the PAP sessions and presents reports to the plenary on the prevailing security situation in Africa and the activities of the council in response to such situations. For instance, Sierra Leone's Ambassador to the Federal Democratic Republic of Ethiopia and Permanent Representative to the African Union, Mr Osman Keh Kamara, made a presentation on behalf of the African Union Peace and Security Council at the 3rd Ordinary Session of the 4th sitting of the Pan-African Parliament which took place on 13 October 2016 in Sharm-el Sheikh, Egypt. ${ }^{33}$ These reports are debated and recommendations are made, where necessary, on how more effectively to address some of the security challenges. ${ }^{34}$

In connection with the oversight functions of the PAP, it is instructive to recall that the leaders of 27 European and 54 African states, as well as the presidents of the continental institutions launched the Joint Africa-EU Strategy (JAES) at the Africa-EU Summit in Lisbon in 2007, setting out the intention of both continents to move beyond a donor-recipient relationship towards long-term cooperation on jointly identified, mutual and complementary interests. ${ }^{35}$

The PAP and the European Parliament, national and regional parliaments, as well as civil societies on both continents should be fully involved in decision-making at their respective levels in order to ensure that there is proper transparency and accountability to all citizens involved in the process. ${ }^{36}$ In particular, the role of the PAP and the European Parliament is to carry out joint monitoring and evaluation on the

\footnotetext{
29 Ibid.: 7.

30 See https://www.aprm-au.org/page-about/, accessed 21 May 2020.

31 ECA (2011: 1, 6-8).

32 NEPAD (2003: para 25).

33 Kabs Kanu (2016).

34 Nwebo (2019: 134).

35 European Commission (2020).

36 Nwebo (2019: 135).
} 
implementation of the JAES. The two parliaments also issued a joint declaration which they presented to the Summit of the African Heads of State and Government of two unions to guide their discussions. ${ }^{37}$

The PAP has various memoranda of understanding (MoUs) for cooperation and collaboration with organisations and international institutions especially in the promotion of constitutionalism and good governance, for instance. ${ }^{38}$ These include the Africa Capacity Building Foundation which, through an agreement with the AUC, supports the advocacy campaigns and capacity-building for the PAP; the European Commission which supports capacity-building efforts of the PAP through provision of resources for staff of the PAP in the finance unit, and in addition supports the advocacy campaign and monitoring and evaluation at the PAP; the Deutsche Gesellschaft für Internationale Zusammenarbeit (GIZ) which supported the recruitment process of the PAP and currently supports the African Governance Architecture programme in which the PAP spearheads the advocacy for the ratification and domestication of AU legal instruments; and the European Parliament which jointly monitors the implementation of the JAES and supports the capacity development of the PAP.

On 10 October 2019 a further and innovative cooperation agreement was signed between Stellenbosch University (through its Development and Rule of Law Programme, DROP) ${ }^{39}$ the PAP, and the German Environment Agency, Umweltbundesamt. ${ }^{40}$ With this MoU, Stellenbosch University enters the realm of academic diplomacy and policy development. On behalf of the PAP, the MoU was signed by its President the Rt Hon. Roger Nkodo Dang. As the PAP is an organ of the African Union established to ensure the full participation of African peoples in the development and economic integration of the continent, its objectives include the promotion peace, security and stability; good governance; and the principles of human rights and democracy in Africa. In support of this mandate, Stellenbosch University's Development and Rule of Law Programme (DROP), which was founded in 2012, is now tasked to cooperate with the PAP in the context of the implementation of the Sustainable Development Goals (SDGs) with regard to policy development projects. The aim is to reconcile tensions between environmental sustainability, economic development, and human welfare, with a focus on burning legal, political, economic and social developments in Africa. Strategic activities at DROP are transdisciplinary in nature, with a strong legal and socio-political focus on climate change, justice, sustainability and transformation. The partners, PAP and DROP have teamed up with the German Environment Agency (UBA), which is Germany's central federal authority on environmental matters under the supervision of the German Federal Ministry for the Environment, Nature

38 Nwebo (2019: 185).

39 Cf. https://drop.sun.ac.za/, accessed 20 May 2020.

40 Cf. Academic diplomacy fostering SDG implementation, at https://bit.ly/3jQpn69, accessed 20 May 2020. 
Conservation and Nuclear Safety (BMU). UBA's main task is to provide science-based policy advice on environmental and sustainable development matters, primarily to Germany's environmental ministry - taking an inter- and transdisciplinary perspective based on about 1,700 employees.

The main objective of the new partnership is to implement the SDGs of the United Nations 2030 sustainability agenda effectively. As a first project, the partners teamed up on the issue of land degradation neutrality (SDG target 15.3) and sustainable soil management on the continent (Article I of the MoU). Another objective of the $\mathrm{MoU}$ is to strengthen the parties' shared interest in and commitment to sustainable soil management, which is essential to achieving land degradation neutrality, which needs to be seen in its wider context.

The publication of this book is a direct outcome of the aforementioned partnership and project. The book was financially supported by the German Ministry for Development Cooperation (BMZ), through the Deutsche Gesellschaft für Internationale Zusammenarbeit (GIZ), and ultimately aims at developing model legislation for sustainable soil management in Africa.

Since the establishment of the SDGs in 2015, there has been a global movement to attain the SDGs - a movement that has been further invigorated by the Coronavirus global pandemic. ${ }^{41}$ Governments, institutions and civil society have all come to the realisation that in order to achieve the SDGs there must be greater collaboration, especially in view of the global social and economic crisis that Covid-19 leaves in its wake. $^{42}$

In the 2020 report on progress towards achieving the SDGs, the Secretary-General, in cooperation with the United Nations system under the United Nations Social and Economic Council, provided an overview of the current situation in terms of the SDGs. ${ }^{43}$ Based on 2019 data, it was acknowledged that there is: ${ }^{44}$

continued unevenness of progress and the many areas where significant improvement is required ... In other areas, however, progress had either stalled or been reversed.

The report pointed out how Covid-19 has had impacts on and implications for all 17 SDGs and "what began as a health crisis has quickly become the worst human and economic crisis of our lifetimes". ${ }^{45}$ Covid-19 has affected operations and institutions across the entire globe, resulting in unplanned delays in the achievement of the SDGs;

41 UN (2020).

42 Gallagher et al. (2020).

43 United Nations Economic and Social Council (2020).

44 Ibid.

45 Ibid. 
however, "[w]hile this crisis is imperilling progress, it also makes [the SDGs'] achievement all the more urgent and necessary". ${ }^{46}$ Although there have been improvements in development across the African continent, a closer look at the continent indicates that there is still a way to go in respect of the SDGs. Economic growth and human development levels have shown a rather bleak situation in statistical terms, with dwindling global trade; depressed commodity prices and a Human Capital Index of less than 0.4; a persistent gap in data, where data are not collected at all or, when they are collected, they are not comprehensive or consistent; governance frameworks to achieve the SDGs are still inadequate; and financing SDG achievement in Africa remains a challenge, which may even be intensifying. ${ }^{47}$

The PAP and its members have committed to a specific role and mandate of African parliaments during the ongoing SDG process. ${ }^{48}$ One recommendation in this regard is to ensure harmonisation with the African Union's Agenda 2063 through integration of the SDG indicators. ${ }^{49}$ African parliamentarians from across the continent have a responsibility - when executing their representative, oversight and legislative roles in terms of the 2030 Agenda implementation - to understand and raise awareness of the SDG framework among constituents; to assess readiness and ensure political neutrality in domesticating the SDG process; and to provide oversight to enhance people's participation. ${ }^{50}$ Parliaments also have an important role to play in facilitating domestic resource mobilisation; in outlining and monitoring budgetary allocations for implementing and reaching targets; in scrutinising national plans to ensure harmonisation and domestication of the SDGs; and in making and reviewing laws to facilitate implementation at the local, national, regional and continental levels. ${ }^{51}$

With this in mind, the PAP serves as a platform for sharing best practices, lessons and challenges in parliamentary engagement on the SDGs. ${ }^{52}$ These include: ${ }^{53}$

developing common strategies for effective parliamentary engagement, as well as promoting partnerships and collaboration between parliamentarians and key development stakeholders.

To achieve this, the respective committees within the PAP can be expected increasingly to monitor progress on the SDGs assigned within their relevant mandate. ${ }^{54}$

46 Ibid: 7.

47 Begashaw (2019).

48 Independent Research Forum (2018: 1, 31).

49 The Independent (2017).

50 Together 2030 (2016).

51 Ibid.

52 Independent Research Forum (2018: 32).

53 Sustainable Development Goals Action Campaign (2016).

54 See https://bit.ly/3c4PEeE, accessed 20 May 2020. 
As a first step, parliamentarians have been undertaking self-assessments in order to gauge whether the work ahead is ensuring that the domestication of the SDGs in their respective countries is people-centred, inclusive and accountable. ${ }^{55}$ Such as $-{ }^{56}$

the leader of Uganda's five-member delegation to the Pan African Parliament, Hon. Jacquilline Amongin, has unanimously been elected chairperson of the Alliance for the Sustainable Development Goals (SDGs) of the PAP. This was during an extraordinary meeting of MPs who subscribe to the alliance from different permanent committees on Wednesday, 16 October 2019 at the side-lines of the 3rd Ordinary Session of the 5th Parliament ongoing in South Africa.

Hon. Amongin, who wrote the Foreword of this book, has been committed to making the PAP a vehicle for achieving sustainable development across the continent.

Moreover, in March 2020, the Permanent Committee on Rural Economy, Agriculture, Natural Resources and Environment gathered during the last day of the Sitting of the Permanent PAP Committees in Midrand, South Africa, to establish the way forward with the development of a soil management model law for the African continent under Committee Chair Hon. Kone Dognon, who said at the commencement:

We are highly encouraged by the dedication to the movement aimed to improve the legal protection mechanisms related to sustainable soil management and give more prominence to land degradation in Africa. Issues of climate change, food security and land use are closely integrated and are cross-cutting in the realisation of the SDGs.

This assignment was undertaken just one year after the successful establishment of the PAP Alliance on the Sustainable Development Goals (ASDGs). ${ }^{57}$ This assignment seems fully in line with Aspiration 1 of the African Union's Vision 2063 (The Future we want), namely a prosperous Africa based on inclusive growth and sustainable development:

By 2063, African countries shall be amongst the best performers in global quality of life measures. This will be attained through strategies of inclusive growth, job creation, increasing agricultural production; investments in science, technology, research and innovation; gender equality, youth empowerment and the provision of basic services including health, nutrition, education, shelter, water and sanitation.

\section{References}

Amadi, E., 2016, "The Pan-African Parliament (PAP): Issues, challenges and prospects". International Journal of Social Sciences and Management Research 2 (1), 5.

Begashaw, B., 2019, "Africa and the sustainable development goals: A long way to go". Africa in focus, at https://www.brookings.edu/blog/africa-in-focus/2019/07/29/africa-and-the-sustainabledevelopment-goals-a-long-way-to-go/, accessed 27 May 2020.

55 Independent Research Forum (2018: 32).

56 Parliament of Uganda (2019).

57 Cf. PAP maps first steps for model legislation on sustainable soil management in Africa, at http://www.panafricanparliament.org/index.php/news-and-events/181-pap-maps-first-stepsfor-model-legislation-on-sustainable-soil-management-in-africa, accessed 20 May 2020. 
Dinokopila, B.R., 2013, “The Pan-African Parliament and African Union human rights actors, civil society and national human rights institutions: The importance of collaboration". African Human Rights Law Journal 13, 302.

ECA / Economic Commission for Africa, 2011, The role of parliament in APRM: Information on how Parliamentarians can participate in APRM. Addis Ababa: ECA, at https://www.uneca.org/archive/sites/default/files/PublicationFiles/5-pamphlet_the_role-of-parliament-in-aprm.pdf, accessed 12 February 2021.

European Commission, 2020, “Africa-EU Cooperation”. International cooperation and development, at https://ec.europa.eu/international-partnerships/africa-eu-cooperation_en, accessed 20 May 2020 .

European Union, 2019, Declaration of the EP-PAP Parliamentary Summit to the IVth Africa-EU Summit. At https://www.africa-eu-partnership.org/sites/default/files/userfiles/final_en.pdf, accessed 13 January 2021.

Gallagher, K.P., W.R. King \& J.A. Ocampo, 2020, "Calibrating the COVID-19 crisis response to the SDGs". Blog, at https://bit.ly/37jDMlV, accessed 27 May 2020.

Independent Research Forum, 2018, Africa's Agenda 2030: Channelling the SDGs toward inclusive, resilient and accountable development. London: IIED, at https://pubs.iied.org/pdfs/G04378.pdf, accessed 13 January 2021.

Kabs Kanu, L.W., 2016, “Ambassador Kamara addresses the Pan-African Parliament on behalf of the African Union Peace and Security Council". News Extra, at http://cocorioko.net/ambassadorkamara-addresses-the-pan-african-parliament-on-behalf-of-the-african-union-peace-and-securitycouncil/, accessed 20 May 2020.

Magliveras, K.D. \& G.J. Naldi, 2003, “The Pan-African Parliament of the African Union: An Overview". African Human Rights Law Journal 3 (2), 222.

Mngomezulu, B.R., 2018, "Reflecting on the Pan-African Parliament: Prospects and challenges" Journal of African Union Studies 7 (2), 45.

Murray, R., 2004, Human rights in Africa: From the OAU to the African Union. Cambridge: Cambridge University Press.

NEPAD / The New Partnership for Africa's Development, 2003, The African peer review mechanism: Base document. NEPAD/HSGIC/03-2003/APRM/MOU/Annex II, at https:/www.un.org/en/africa/osaa/pdf/aprm-basedoc.pdf, accessed 13 January 2021.

Nwebo, O.E., 2019, The role of the Pan African Parliament in promoting constitutionalism and democratic governance in Africa: Lessons from other supranational parliaments. LLD thesis, University of Pretoria.

OAU / Organization of African Unity (Assembly of Heads of State and Government), 1999, Decision on the convening of an extraordinary session of the OAU Assembly of Heads of State and Government in accordance with Article 33(5) of its Rules of Procedure. (Algiers 1999) AHG/Dec. 140 (XXXV).

PAP / Pan African Parliament, 2020, "Background". About Us, at http://www.panafricanparliament.org/index.php/background, accessed 20 May 2020.

Parliament of Uganda, 2019, "Uganda takes leadership of PAP Alliance on SDGs", at https://www.parliament.go.ug/news/3808/uganda-takes-leadership-pap-alliance-sdgs, accessed 20 May 2020.

Sustainable Development Goals Action Campaign, 2016, "African Parliamentary Conference on the SDGS”. Field story in Africa, at https://sdgactioncampaign.org/2016/03/15/AFRICAN-PARLIAMENTARY-CONFERENCE-ON-THE-SDGS/, accessed 20 May 2020. 
The Independent, 2017, "Pan African Parliament MPs call for review of SDGs". Africa, at https://www.independent.co.ug/pan-african-parliament-mps-call-review-sdgs/, accessed 20 May 2020.

Together 2030, 2016, "The role of parliamentarians in the implementation of the 2030 Agenda for Sustainable Development". 4th implementation series webinar, at https:/www.together2030.org/wp-content/uploads/2016/12/FINAL-Closed-Captioning-May-17-Webinar-Roleof-Parliamentarians.pdf, accessed 20 May 2020.

UN / United Nations, 2020, "Dispatches from the field: Scientists, experts and policy makers addressing the Covid-19 crisis around the world". Covid-19: Dispatches from the field, at https://sustainabledevelopment.un.org/blog/covid19, accessed 27 May 2020.

United Nations Economic and Social Council, 2020, Progress towards the sustainable development goals. Report of the Secretary-General, at https://bit.ly/2MZ9M81, accessed 27 May 2020. 
